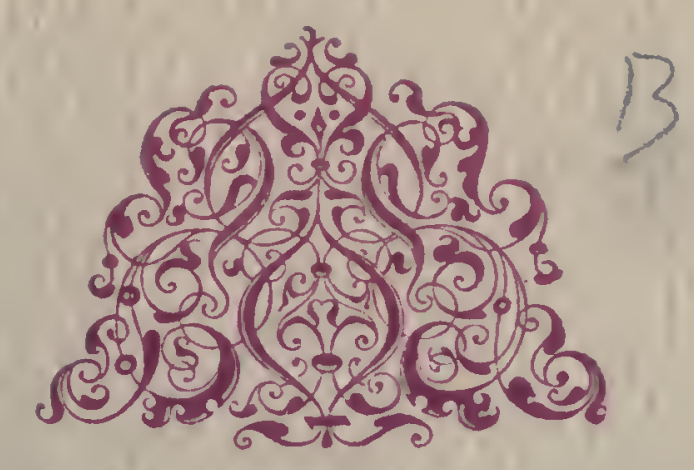

\title{
Renaissance \\ and \\ Reformation
}

VOLUME VIII 197 I NUMBER 1

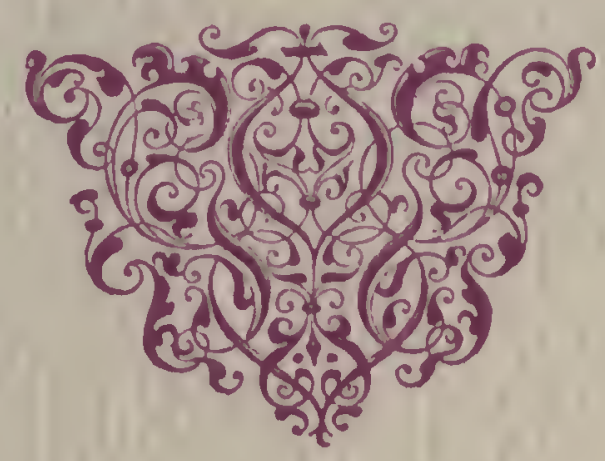


Renaissance and Reformation is published 3 times a year (September - June)

(c) the University of Toronto Renaissance and Reformation Colloquium the Victoria University Centre for Renaissance and Reformation Studies (CRRS), 1971

\author{
Editor \\ Julius A. Molinaro \\ Associate Editor \\ M. R. Maniates \\ Editorial Assistant \\ Walter Dedi \\ Editorial Committee \\ Co-Chairmen \\ C. Edward Rathé (York University) \\ H. R. Secor \\ J. M. Estes \\ V. E. Graham \\ F. J. D. Hoeniger \\ J. K. McConica \\ Marshall McLuhan \\ John Meyer (McMaster University) \\ J. H. Parker \\ Brayton Polka (York University) \\ Patricia Vicari
}

Subscription price is $\$ 2.50$ per year. Manuscripts should be accompanied by a self-addressed, stamped envelope and follow the revised edition of the MLA Style Sheet.

Manuscripts should be addressed to:

The Editor

Renaissance and Reformation

Dept of Italian \& Hispanic Studies

University of Toronto

Toronto 5, Canada

All communications, including notices of changes of address, enquiries and subscriptions should be sent to:

Leslie T. McCormick

Business Manager

Renaissance and Reformation

Erindale College

3359 Mississauga Rd.

Clarkson, Ontario, Canada 


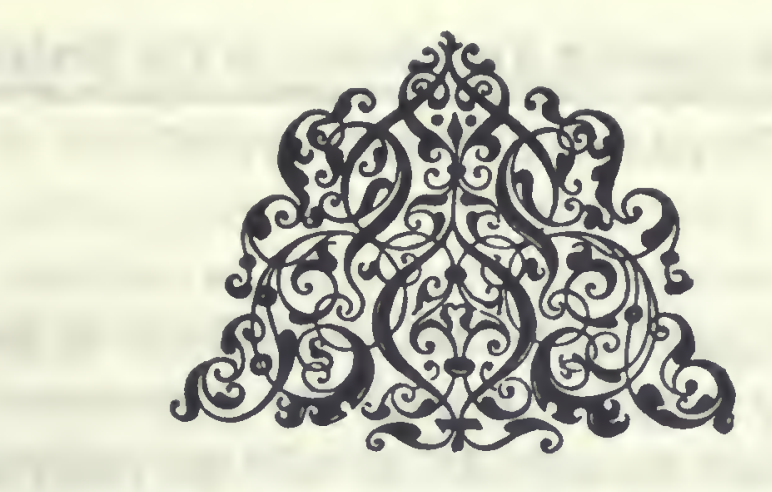

\section{Contents}

2

The Classics and their Spanish Translators in the Sixteenth Century THEODORE S. BEARDSLEY, JR.

10

The Third Book of the Orlando Innamorato; Notes on the Venetian Edition ANTONIO FRANCESCHETTI

14

Additional Sources for French Politico-Religious History (1562-1646) in the University of Toronto Library

EDMOND M. BEAME

32

BOOK REVIEWS

MARIA RIKA MANIATES

Gerald Abraham, ed., The Age of Humanism, 1540-1630

(The New Oxford History of Music, Vol. IV)

H. H. BEN-SASSON

Salo Wittmayer Baron, A Social and Religious History of the Jews: Vols. XIII and XIV F. M. WEINBERG

Thomas M. Greene, Rabelais; a Study in Comic Courage BODO L. O. RICHTER

Terence C. Cave, Devotional Poetry in France c.1570-1613

PEDRO R. LEÓN

Ramón Iglesia, Columbus, Cortés, and Other Essays

R. B. PARKER

David Galloway, ed., The Elizabethan Theatre II

PETER V. MARINELLI

John L. Lievsay, The Englishman's Italian Books 1550-1700

Renaissance and Reformation VOLUME VIII 1971 NUMBER 1 